\title{
INSTITUTE AFFAIRS
}

\section{OFFICERS OF STANDING COMMITTEES}

\section{Forest Entomology \& Forest Pathology:}

Chairman-R. R. Lejeune, Forest Insect Lab., Box 156, University of Manitoba, Winnipeg, Man.

Secretary - W. B. G. Denyer, Dom. Lab. of Forest Pathology, 309 Birks Bldg., Saskatoon, Sask.

\section{Forest Fire:}

Chairman-J. C. MacLeod, Forestry Branch Department of Resources and Development, Ottawa, Ont.

Secretary -A. W. Braine, Chief of Forest Protection, Manitoba Forest Service, Winnipeg, Man.

Land Tenure and Taxation:

Chairman-J. Miles Gibson, University of New Brunswick, Fredericton, N.B.

\section{Reforestation:}

Chairman-To be appointed.

Secretary -A. H. Bamford, 201, 1162 Fort Street, Victoria, B.C.

Silviculture:

Chairman-Dean George S. Allen, Faculty of Forestry, University of British Columbia.

Secretary -V. H. Phelps, 813 Dom. Public Bldg., Winnipeg, Man.

Soils and Site:

Chairman-G. Angus Hills, Box 242, Thornhill, Ont.

Secretary -N. Kissock, Marathon Paper Mills Ltd., Port Arthur, Ont. Surveys:

Chairman-H. E. Seely, Forestry Branch, Department of Resources and Development, Ottawa, Ont.

Wildlife:

Secretary -W. H. Hilborn, Fredericton, N.B., Univ. of N.B.

Chairman-C. David Fowle, Division of Research, Ontario Dept. of Lands and Forests, Toronto, Ont.

Secretary -J. F. S. Bendell, Dept. of Biology, Queen's University.

Woodlot Management:

Chairman-J. L. Van Camp, Gen. Mgr. Can. For. Assoc., 4795 St. Catherine St., Montreal 6, P.Q.

Secretary - M. R. Wilson, Extension Forester, Cdn. Intern. Paper Co., Montreal, Que.

Wood Utilization:

Chairman-J. H. Jenkins, Chief of Forest Products Laboratories Division, Forestry Branch, Department of Resources and Development, Ottawa, Ont.

Secretary - C. R. Silversides, Abitibi Power \& Paper Co. Ltd., 408 University Ave., Toronto, Ont. 


\section{SECRETARY-TREASURER'S REPORT-1954 1}

This report covers the activities of the Institute from October 1953 to October 1954. The attached financial statement covers the twelve month period from June 30, 1953 to June 30, 1954.

The financial statement of the Institute, which has been discussed by the Board of Directors at the meeting held on Tuesday, October 12, indicates no irregularities. The rather large amount of cash in the bank is to be reduced by the purchase of $\$ 3,000$ worth of Dominion of Canada Bonds. Due to increased activity in Institute business, Mrs. Mathews has been working practically full time and thus office salaries are somewhat higher. In this regard, however, I would like to emphasize that the Institute is getting loyal efficient service that few other organizations enjoy at any price. The net surplus of operations of $\$ 2,158.73$ compares favorably with that of last year $\$ 904.45$. The only investment in fixed assets was the purchase of an adding machine at a cost of $\$ 155.00$.

As you may be aware, at the 1953 meeting of the Board of Directors, I tendered my resignation which was to take effect at this Annual Meeting. A committee of three consisting of the President, the Vice-President and the Secretary-treasurer was appointed by the Board to find a replacement. It is expected that an appointment will be made in the near future.

\section{Institute Officers}

All of the Institute officers, President, Vice-President and Editor of the Forestry Chronicle have been extremely helpful in conducting the business affairs of the Institute which are, of course, the responsibility of the Secretary primarily. Much remains to be done, however, and until we are able to employ a manager who can devote at least half his time to Institute work, many worthy undertakings will have to remain undone. Without a half-time manager on the job, much of the work of the institute falls on the President and Vice-President, and during my term of office the Institute has been singularly fortunate in its selection of these officers. Being President of the Institute is not an easy task under the present set up of the organization, and we owe a hearty vote of thanks to those who accept the responsibility. Work which is perhaps more easily recognized by the average member is that contributed by our hard-working Editor, who has contributed most generously of his ability and performed his tasks with enthusiasm and efficiency.

\section{Schlich Memorial Fund}

In the year 1953-54 the award was made to the University of Toronto and was won by Fred Motyl.

\section{Institute Gold Medal Awards}

The C. I. F. Gold Medal Awards authorized by the 1953 meeting of the Board of Directors were distributed for the first time in 1954 and were won by University of B. C.-Robert S. Wood; University of Toronto-Robert D. Carman; University of Laval-Louis Rousseau and University of New Brunswick-Louis Schulte.

\footnotetext{
${ }^{1}$ Report presented at the C.I.F. Annual Meeting held Oct. 13 to 15, 1954 at Victoria, B.C.
} 
Letters of appreciation from the Universities, at the time of the announcement of the awards and letters from the recipients, indicate that these awards were very well received indeed.

\section{Membership}

At this time it seems appropriate that I briefly review changes in the membership picture that have taken place since I took over the secretaryship of the Institute in 1948.

$\begin{array}{lrr} & 1948 & 1954 \\ \text { Honorary } & 10 & 10 \\ \text { Active } & 673 & 1287 \\ \text { Affiliate } & 49 & 121 \\ \text { Students } & - & 35 \\ \text { Total members } & \mathbf{7 3 2} & 1453\end{array}$

In this brief period of six years the membership has almost doubled.

\section{General Activities}

In addition to the normal routine of Head Office-which includes the collecting of dues, the amending of the mailing list, processing of applications, distributing Presidents' reports and despatching routine correspondence and notices-the Head Office submitted two reports to members; completed arrangements for the awarding of the C. I. F. Gold Medals; made arrangements for the production and distribution of the C. I. F. Pins and obtained authority from the Board of Directors to accredit a few foreign universities.

\section{A Critical Look at the C. I. F.}

I know that I am not the one best able to take a critical look at the C. I. F., but other people do not seem to be inclined to do so and once in a while it is perhaps stimulating to undertake a little constructive self-criticism, at least it may avoid the development of a smug attitude.

Permanent Secretary-The impression held by many members appears to be that the work of the Institute cannot progress satisfactorily until we have a full time manager. No one knows better than I, how much we need a permanent secretary-manager, but I cannot bring myself to believe that such a man is going to make any tremendous changes which will make the Institute much more effective as far as the average member is concerned. There is no point in using the lack of adequate managerial assistance as an excuse for action. The job analysis of the position of secretary-manager of the C. I. F. suggests that in general the strength and accomplishments of the C. I. F. will still depend on the activity and interest taken by the average member, largely on his own initiative. Benefits are derived from the Institute in the proportion in which energy and interest are invested-and it will always be thus-manager or no manager.

National Projects-In the six years that I have been secretary, few national projects worthy of the name have been undertaken. I do not blame this on our lack of a full time manager. We have from time to time conducted national ballots on such items as by-laws, pins and certificates and numerous other items of non-technical significance. I do feel that a technical organization such as 
this cannot remain healthy or progress unless it undertakes national projects of technical significance. For instance, a typical subject of current interest is the Canada Forestry Act and its application, but no national discussion of this Act was undertaken by the C. I. F. although a committee did prepare a report on the implementation of the Act. The point is that members who are unable to attend annual meetings are not encouraged to express opinions on technical forestry problems of national interest.

Reluctance to Accept Responsibility-The Institute has never, to my knowledge, defined its obligations to the country. We have, of course, prepared a very worthy "Statement of Forest Policy" but without exception this Policy relates to practices or actions which can only be initiated by some other organization-federal or provincial governments or industry. There is no definition of the obligations of our professional organization and no proposals with respect to action that we ourselves should take.

Do we have any obligations as a professional group? I think we have very definite obligations. We have with agriculture, a background of understanding with respect to the utilization of land-this knowledge and understanding is basic-it is entirely fundamental to optimum development of our country. One of our obligations is to see that this land is used in the best interests of present and future generations. In spite of this we rarely express an opinion on land use. We have many other less fundamental but more readily definable obligations which I cannot discuss at length in the report, but which require study by us. We need another statement of forest policy-this one defining our own obligations and suggesting means of fulfilling them.

Foresters in Canada are in a unique and not entirely enviable position. Generally speaking foresters work either for government or big business. There are relatively few in the very favorable position of having no prescribed policy within the bounds of which they must function. Consultants and other unattached individuals, while of top quality, have until very recently been few in number and have not, with a few notable exceptions, taken much interest in promoting reforms which may be basic to the practice of forestry in this country.

This means that the only group capable of giving authoritative and unbiased expression of professional opinion on basic forestry principles is the C. I. F. In spite of this the $C$. I. F. has rarely exercised its prerogative in this regard.

It has been suggested to me that the C. I. F. is too small, that if we had four thousand members and more physical stature, we would then be in a position to speak up. It seems to me that, provided we are united in our expressions of opinion and provided that opinion is sound and expressed with confidence, it will be beeded. It is important that we keep our eyes on developments and that we study them-not sponsoring a resolution hastily drafted at an annual meeting, but sponsoring a thoroughly considered and maturely discussed opinion developed on a national level一and that we then express our considered opinion whether it be a criticism or a compliment.

Sections-This year section reports contain little of national significance. This may be the result of modesty on the part of the section secretaries, but I rather fear that it is in fact the truth that sections have not in general been active on any projects of more than casual significance. 
As with individual membership, sections too will only reap what they have sowed. If they are prepared to undertake worthy projects that they can get their teeth into, they will progress in membership and in national prestige; if they are satisfied to build their entire program around a monthly movie or speaker, they will not progress.

Committees-With a few notable exceptions the activity of technical standing committees is at an extremely low ebb. This may be due to the basic organization or a temporary lapse of interest on the part of committee officers, but it is surely an unhealthy condition that must be rectified. For one thing more of the younger members must be given a chance to show their stuff in committee activity as they are doing in the sections.

General-Throughout all this lengthy dissertation one fault shows clearly to me-we are not engaged either in committees, sections or on the National level in the study and promotion of technical forestry objectives. If we do not move forward through greater activity, we will surely move backward.

In closing may I take this opportunity to thank all of you who have been so understanding and helpful to me in the execution of my responsibilities as Secretary-treasurer. You have been most helpful and it has surely been a great pleasure and a great opportunity for me to have been associated with you these six years. In truth it is with much sadness that I withdraw from the C. I. F. executive.

D. V. Love, Secretary Treasurer.

Dave Love Retires as Secretary-Treasurer of the C.I.F.

After filing his last annual report as Secretary-Treasurer of the C.I.F. in which he constructively criticized the C.I.F. for its lethargy in accepting its place as representative of the thinking of Canadian foresters and spokesman for Canadian forest policy, Dave Love followed his previously announced intentions and retired from the post which he had held for six years. Anyone who has been active in the C.I.F. business during that time knows the amount of interest Dave has displayed and the amount of energy he has given on a spare-time basis to keep the Institute rolling along smoothly. To Dave goes the sincere thanks of the membership of the C.I.F. for all his past efforts and enthusiasm.

Replacing Dave in this responsible post is James D. Coats who was born in Winnipeg in 1928. Jim went to school in Winnipeg, took his first year of science at the University of Manitoba, his second at United College, Winnipeg, and four years of Forestry at University of Toronto. Jim has been active in a variety of Forestry work. He has had field experience with the Forest Insect Laboratory in Manitoba; with Photographic Survey Corp., Alberta; with the Dominion Forest Branch, Alberta; and has worked with the Canadian Forestry Association in the Prairie Provinces and Ontario. During the past few years, he has been an active member of the Southern Ontario Section of the C.I.F.

$\mathrm{Jim}$ attributes an early interest in forestry to the enthusiasm of $\mathrm{Hec}$ Richmond who was a neighbor in Winnipeg. Hec is now with the Vancouver Island Section.

We all wish Jim every success in his new and difficult task as SecretaryTreasurer of the Canadian Institute of Forestry. 